University of Chicago Law School

Chicago Unbound

\title{
A Reader's Companion to Against Prediction: A Reply to Ariela Gross, Yoram Margalioth, and Yoav Sapir on Economic Modeling, Selective Incapacitation, Governmentality, and Race
}

Bernard E. Harcourt

Follow this and additional works at: https://chicagounbound.uchicago.edu/journal_articles

Part of the Law Commons

\section{Recommended Citation}

Bernard E. Harcourt, "A Reader's Companion to Against Prediction: A Reply to Ariela Gross, Yoram Margalioth, and Yoav Sapir on Economic Modeling, Selective Incapacitation, Governmentality, and Race," 33 Law and Social Inquiry 265 (2008).

This Article is brought to you for free and open access by the Faculty Scholarship at Chicago Unbound. It has been accepted for inclusion in Journal Articles by an authorized administrator of Chicago Unbound. For more information, please contact unbound@law.uchicago.edu. 


\section{A Reader's Companion to Against Prediction: A Reply to Ariela Gross, Yoram Margalioth, and Yoav Sapir on Economic Modeling, Selective Incapacitation, Governmentality, and Race}

Bernard E. Harcourt

From parole prediction instruments and violent sexual predator scores to racial profiling on the highways, instruments to predict future dangerousness, drug-courier profiles, and IRS computer algorithms to detect tax evaders, the rise of actuarial methods in the field of crime and punishment presents a number of challenging issues at the intersection of economic theory, sociology, history, race studies, criminology, social theory, and law. The three review articles of Against Prediction: Profiling, Policing, and Punishing in an Actuarial Age by Ariela Gross, Yoram Margalioth, and Yoav Sapir, raise these challenges in their very best light. Ranging from the heights of poststructuralist and critical race theory to the intricate details of mathematical economics and criminological analysis, the articles apply different disciplinary lenses to the analysis of the actuarial turn offered in Against Prediction and set forth both substantive and structural challenges to the book. By means of a detailed reply to the three reviews, this article provides a reader's companion to Against Prediction.

Bernard E. Harcourt is the Julius Kreeger Professor of Law and Criminology at the University of Chicago and a visiting professor at the École des Hautes Études en Sciences Sociales and the Université de Paris X. I am deeply grateful to Ariela Gross, Yoram Margalioth, and Yoav Sapir for their insightful readings and critiques of Against Prediction: Profling, Policing, and Punishing in an Actuarial Age, to Shai Lavi, the Taubenschlag Institute of Criminal Law and the faculty at Tel Aviv University for a fascinating symposium on the book, to Martha Minow and Carol Steiker for detailed comments on an early draft, to Mariana Valverde and Andrew Dilts for comments and stimulating conversations on Foucault's Collège de France lectures, and to Pat O'Malley, Frederick Schauer, Susan Silbey, Tanina Rostain, and Lucia Zedner for rich debates. I can be contacted at harcourt@uchicago.edu. 


\section{INTRODUCTION}

In Against Prediction: Profiling, Policing, and Punishing in an Actuarial Age (2007), I trace the rise of actuarial methods in the field of crime and punishment and offer three critiques of the use of accurate actuarial instruments. First, assuming a rational choice framework, the use of profiling techniques may actually increase crime in society under reasonably conservative assumptions. Therefore, profiling may be inefficient to the law enforcement goal of reducing crime. Second, putting aside rational choice premises and assuming only selective incapacitation, the use of actuarial instruments may produce a ratchet effect on members of the profiled population with highly detrimental consequences on their employment, educational, familial, and social outcomes. Third, the embrace of actuarial methods distorts our conceptions of just punishment by displacing a fundamental principle, namely that similarly situated persons should be treated equally regardless of race, gender, national origin, or other group-identifying traits. For all of these reasons, the presumption in the field of crime and punishment should be against prediction.

The insightful review essays of Ariela Gross, Yoram Margalioth, and Yoav Sapir raise a number of challenges at the intersection of economic modeling, social theory, history, race studies, and law. Ranging from the heights of poststructuralist and critical race theory to the intricate details of mathematical economics and criminological analysis, the articles pose important questions about each one of the three critiques in Against Prediction, as well as larger structural issues about the book. In order to accompany the reader systematically through the three critiques, I will address the review articles starting with the economic modeling. I will also begin with the substantive challenges and then turn to larger structural considerations.

It is rare indeed to have the opportunity to revisit a book one has written and published, especially a book that has been the subject of such close readings and critiques. It presents a unique occasion to clarify and reframe the written text. I offer this article, then, as a reader's companion to Against Prediction.

\section{REVISITING THE THREE CRITIQUES}

\section{Efficiency, Pure Theory, and the Full Economic Model}

The use of actuarial methods-which I define specifically as prediction instruments that rely on statistical disparities between group offending rates (Harcourt 2007a, 1)-may backfire and increase crime under conservative assumptions. If members of the profiled group are less elastic to policing than members of the nonprofiled group - if they respond less intensely and are less deterred by any increased surveillance-then profiling them for purposes 
of policing and punishment may be inefficient to the law enforcement objective of reducing crime. ${ }^{1}$

In his article "Looking at Prediction from an Economics Perspective," Margalioth argues that this first critique is technically accurate with regard to existing profiling techniques, but that the existing techniques are error-prone insofar as they do not incorporate a measure of the comparative responsiveness of the different populations. Though technically accurate, Margalioth emphasizes, my first critique should not undermine our faith in the efficiency of profiling techniques when they are properly administered. The correct use of statistical discrimination is "always efficient in theory," (Margalioth 2008, 244, see this issue) Margalioth writes. An argument against profiling "may be justified only if interpreted as a positive account that criticizes the current, misguided, use of profiling" (244). As a result, Margalioth urges that we not be against prediction but only against our current practices of profiling.

Margalioth and I are entirely in agreement on this important theoretical point, which in fact is the very basis of my first critique. There is no question that if we had perfect information on the comparative elasticities and offending rates of the two groups at the margin, then we could administer statistical discrimination efficiently and ensure that there are no negative effects on crime. I demonstrate this in Against Prediction using an economic model of the social costs associated with profiling and crime. More specifically, I use a traditional cost function to derive the precise first-order condition that must necessarily be met in order for profiling to increase social welfare by decreasing total social costs (Harcourt 2007a, 133). I find that profiling will only decrease costs in society - and therefore be efficient-under specific conditions relating the comparative elasticities and offending rates to the comparative internal search rates of the two different groups. ${ }^{2}$

To help visualize this first-order condition, I use the case of racial profiling and demonstrate how to profile efficiently in one simple table (134). I will add a few identifiers to the cells in order to facilitate the discussion and reproduce the full table here. For purposes of the table, $E_{M}$ stands for the elasticity of minorities and $E_{W}$ for the elasticity of whites; $O_{M}$ for the offending rate of minorities and $O_{W}$ for the offending rate of whites; and $I_{M}$ for the internal search rate of minorities and $I_{W}$ for the internal search rate of whites:

1. The term "elastic to policing" or more generally the notion of the "elasticity of offending to policing" refers to the degree to which changes in policing affect changes in offending. For example, an individual who is very elastic to policing will decrease his offending a lot when he is policed more; an individual who is less elastic to policing will decrease his offending less in response to the same increase in policing.

2. The exact equation is specified at Harcourt $(2007 \mathrm{a}, 133)$ but is rewritten here using a bit more English: Elasticity $y_{\text {profled }} \times\left(\right.$ Offending $_{\text {profiled }} /$ SearchRate $_{\text {profled }}$ ) $=$ Elasticity $_{\text {non-profled }} \times$ (Offending non-profiled $/$ SearchRate $_{\text {non-profiled }}$ ) 
TABLE 1.

Minimizing Total Social Costs

\begin{tabular}{|c|c|c|c|}
\hline & $E_{M}=E_{w}$ & $E_{M}<E_{w}$ & $E_{\mathrm{M}}>E_{\mathrm{W}}$ \\
\hline$O_{M}=O_{W}$ & $\begin{array}{l}\text { [1] } I_{M}=I_{W} \\
\text { (No Racial Profiling) }\end{array}$ & $\begin{array}{l}\text { [2] } I_{M}<I_{W} \\
\text { (Profile Whites) }\end{array}$ & $\begin{array}{l}\text { [3] } I_{M}>I_{W} \\
\quad \text { (Profile Minorities) }\end{array}$ \\
\hline$O_{M}>O_{W}$ & $\begin{array}{l}\text { [4] } I_{M}>I_{W} \\
\text { (Profile Minorities) }\end{array}$ & $\begin{array}{l}\text { [5] } \mathrm{I}_{M}<I_{W}\left[O_{M} / O_{W}\right] \\
\text { (Depends) }\end{array}$ & $\begin{array}{l}\text { [6] } I_{M}>I_{W} \\
\text { (Profile Minorities) }\end{array}$ \\
\hline$O_{M}<O_{W}$ & $\begin{array}{l}\text { [7] } I_{M}<I_{W} \\
\text { (Profile Whites) }\end{array}$ & $\begin{array}{l}{[8] I_{M}<I_{W}} \\
\quad \text { (Profile Whites) }\end{array}$ & $\begin{array}{l}\text { [9] } I_{M}>I_{W}\left[O_{M} / O_{W}\right] \\
\text { (Depends) }\end{array}$ \\
\hline
\end{tabular}

The first full row of the table addresses the situation where both minorities and whites have the same offending rates. Cell 1 tells us that if the two groups also have identical responsiveness to policing, then law enforcement should not engage in any form of racial profiling but should instead police color blind. Cell 2 tells us that if minorities have lower elasticity than whites, then the police should profile whites; and cell 3 tells us the inverse: if minorities have greater elasticity than whites, then the police should profile minorities.

The second full row addresses a situation where minorities have a higher offending rate than whites. Cells 4 and 6 tell us that profiling minorities will be efficient and reduce overall social costs if the elasticity of minorities is greater than or equal to the elasticity of whites. However, cell 5 tells us that if minorities are less elastic to policing, then profiling minorities will only be efficient if the ratio of minority to white internal search rates is less than the ratio of minority to white offending rates. The third full row addresses a situation where whites have a higher offending rate than minorities and is essentially the reverse image of the second full row.

Margalioth writes in his essay, "In fact, if we assume, as Harcourt does, that [minorities] have lower elasticity compared to whites, this does not mean that racial profiling is not efficient. It means that using racial profiling to target whites may minimize total criminal activity" (Margalioth 2008, 248). Margalioth is absolutely right and his argument is reflected in cells 2, 5, and 8. Notice that in cell 5-under conditions of lesser minority elasticity but higher minority offending-we should only target whites on efficiency grounds depending on the exact relationship between comparative offending rates and comparative internal search rates.

The table demonstrates that, if we knew the exact comparative elasiticities, offending, and internal search rates, then we could determine whether and whom to profile perfectly efficiently. In this sense, at the level of pure theory, the use of statistical discrimination is indeed always efficient.

Where Margalioth and I part ways, though, is on the importance to place on the theoretical versus the actual. The fact is, we do not have any 
data on comparative elasticities, and, until now, the social scientists who have been working on these actuarial instruments have never paid any attention to comparative elasticities. From the very first prediction tool onwards, researchers have based their instruments on comparative offending rates as the outcome measure. From Ernest Burgess (Bruce, Burgess, and Harno 1928), who developed the very first prediction tables implemented in the twentieth century, to the DEA agents who developed the drug-courier profile in the 1970 s to the most up-to-date sexual offender risk assessment instrumentsall of the profiling instruments are based on offending differentials only. In other words, throughout the twentieth century and now into the twentyfirst, actuarial methods are tied to differences in offending rates. The actuarial research-practical and theoretical-has never measured comparative elasticities. The result is that, today, we know effectively nothing about comparative elasticities. ${ }^{3}$ It is precisely for this reason, incidentally, that I defined "actuarial methods" narrowly and specifically at the outset of Against Prediction as the "use of statistical rather than clinical methods on large datasets to determine different levels of criminal offending associated with one or more group traits, in order (1) to predict past, present, or future criminal behavior and (2) to administer a criminal justice outcome" (Harcourt 2007a, 1, emphasis added). This definition reflects, most accurately, what actuarial methods mean today and for the foreseeable future.

The pure theory of statistical discrimination is so divorced from our current state of knowledge and from our existing profiling techniques that the more meaningful conclusion to draw is that our actuarial instruments are potentially inefficient. Today and for the foreseeable future, we should remain against prediction.

These remarks help clarify two other important points that Margalioth raises in his article. First, as Margalioth writes, "The difference in group size is irrelevant" (Margalioth 2008, 249). Margalioth is right, and if there is

3. It is only within the timeframe of the writing of this book and the earlier articles from which it grew (Harcourt 2004, 2003a, 2003b) that researchers have begun to consider the implication of comparative elasticities to profiling. At the theoretical level, Nicola Persico (2002) raised the possibility of inefficiency in an article in 2002 , but only recently have comparative elasticities begun to be included in the mathematical models (Harcourt 2004; Dominitz and Knowles 2005; Blumkin and Margalioth 2006; Bjerk 2007). At the empirical level, Avner Bar-Ilan and Bruce Sacerdote have a working paper from 2001 that explores the comparative responsiveness to an increase in the fine for running a red light along several dimensionsfinding that the elasticity of red light running with respect to the fine "is larger for younger drivers and drivers with older cars," equivalent for drivers "convicted of violent offenses or property offenses," and smallest, within Israel, for "members of ethnic minority groups" (2001, $1-2)$. In addition, Paul Heaton has a 2006 working paper on the effect of eliminating racial profiling policies in New Jersey on the offending of minorities; however, the policing intervention in New Jersey involved no de-policing of whites, so there is no proper way to assess how the elasticity of black offenders compared to that of whites. The bottom line is that we still do not know anything about real comparative elasticities in the United States. 
anything in Against Prediction that suggests otherwise, it is the inadvertent product of trying to make the proofs accessible without using calculus. ${ }^{4}$ Group size does not matter to the first-order condition for efficiency. This should be evident from the equation and the table reproduced above: there is nothing in the equation or in the table that goes to the relative sizes of the populations. If there is any confusion in the text of Against Prediction, I would like to clarify the point here: group size does not matter.

Second, as I emphasize in the text, I do not know how the elasticies compare as between minorities and whites-or for that matter as between any two groups in society. ${ }^{5}$ This is, as Margalioth suggests, an "open question" (248) as an empirical matter. My purpose in the text is not to claim that profiled groups have lower elasticity but rather to suggest that there are common sense reasons to suspect that a group with a higher offending rate may also have lower elasticity than the general population. The reasons are that there may be antecedent conditions-socioeconomic, educationrelated, familial, cultural, or other-that explain both the higher offending and any potential difference in elasticity. This is, however, a theoretical claim for which there is at present no empirical evidence-which is precisely the problem.

\section{The "Ratchet Effect," Selective Incapacitation, and Social Engineering}

If we put aside for a moment all rational choice assumptions and imagine that people are perfectly inelastic to policing, then the use of actuarial methods will be an efficient means to detect more crime. Profiling will increase the effectiveness of policing and punishing. But these benefits come at a price: the use of actuarial methods will cause a "ratchet effect" (Harcourt 2007a, 3 ) on the profiled population, such that members of the profiled group will be overrepresented in terms of carceral contacts (arrests, searches, detentions,

4. Margalioth is right that I do discuss group size in some of the early models on pages 126 and 131 and in Appendix B. The reason is that, in those models, I am using real (though hypothetical) numbers to make the analysis clear to the lay reader. I was trying to avoid using calculus as much as possible to make the proofs more accessible, and those early models therefore use actual numbers and proportions. But in the formal and exact model that uses derivatives, it is clear that the proportional size of the groups does not matter to the first-order condition for efficiency.

5. This is especially true in the context of profiling as a counterterrorism measure. As I discuss in Against Prediction (2007a, 227-36) and develop at further length in "Muslim Profiles Post 9/11" (forthcoming), it is extremely difficult to know how the elasticities of different groups compare in the terrorism context. The efficiency of profiling will tum on whether any immediate gains from profiling will be offset by long-term substitution effects-that is, by whether terrorist organizations can recruit from outside the profiled group-but those longterm effects are extremely hard to predict precisely because of the uncertainty surnounding the comparative elasticities. 
convictions, incarcerations) in relation to their representation in the offending population.

The basic intuition is that policing is like sampling: when the police profile higher-offending individuals, they are effectively sampling more from that higher-offending group. The resulting set of successful searches will contain a disproportionate number of those high-offending individuals-disproportionate as compared to their representation in the offending population. This imbalance will get incrementally worse each year if law enforcement departments rely on the evidence of last year's correctional traces-arrest or conviction rates-in order to set next year's profiling targets. The resulting ratchet effect will have significant detrimental consequences on the employment, educational, familial, and social outcomes of the profiled populationsincluding, in the case of racial profiling, the devastating effects associated with the notion of black criminality that pervades the public imagination (Roberts 1999, 805) and, in the case of recidivists, the extreme difficulties of prisoner reentry (Travis 2000). The high costs associated with any ratchet effect should temper our embrace of the actuarial.

None of the review articles challenge the idea of a ratchet under conditions of nonelasticity. Margalioth correctly observes that if the populations are completely inelastic, then a perfectly efficient police officer would always and exclusively want to search members of the higher-offending group. On efficiency grounds, the police would not ratchet up, but rather search only the profiled population. Margalioth is right that this would eliminate subsequent ratchets-in other words, that it would eliminate subsequent ratchets as incremental processes operating over time. It would not, however, eliminate a one-time ratchet that would create the full disparity. As a result, the consequences are similar. Whether the ratchet occurs in one period only or over time, it would create a stark imbalance between the offending and carceral distributions with detrimental effects on the profiled population.

In his article "Against Prevention?," however, Yoav Sapir does urge me to go further in my critique. Sapir argues that if we assume that the predictions are accurate- - a point I will return to later-then we may need additional arguments against selective incapacitation. "If it does in fact work and if we can predict who is likely to reoffend," Sapir asks, "is it not legitimate to put them away for a longer period of time? Don't we need more robust reasons to be opposed to selective incapacitation?" (Sapir 2008, 260, see this issue).

Sapir offers two additional reasons. The first is that incapacitation punishes for suspicious traits and future acts rather than for the past criminal act itself: "we do not punish people for wrongs they did, but we make them suffer for possessing certain traits or belonging to certain groups" (260). I agree with this first argument and believe that it is reflected in my third critique-namely that actuarial methods distort our fundamental 
principle that equally situated persons should be treated alike. Selective incapacitation no longer treats offenders as equals for having committed a crime, but instead looks at group traits-race, prior record, family background-to determine similarity. Like Sapir, I find this deeply troubling.

Sapir's second argument is that incapacitation amounts to "the state's shirking its responsibility to deal with the causes of crime" (260). The turn to actuarial methods and selective incapacitation, Sapir notes, is "a reflection of the fact that we have given up on trying to reduce crime by investing in job opportunities, education, assistance to immigrants, drug rehabilitation programs, reentry programs, and the like. We have also given up on punitive measures that keep the offender in the community" (260). On this score, I must confess, I am no longer convinced that the state is in a strong position to identify properly the causes of crime or to propose the kinds of solutions that I might agree with. I have become increasingly skeptical of our ability to empirically verify criminological and punishment theories, especially those that intermediate through human consciousness, such as deterrence and rehabilitation theories, as well as social influence and legitimacy theories. I have found that even the most technical and savvy statistical analyses, econometric models, and qualitative research often fall short of their stated conclusions (Harcourt 2006b, chap. 14). I have sketched out my increasing skepticism about the role of scientific discourse in the field of crime and punishment in a recent article titled "Post-Modern Meditations on Punishment: On the Limits of Reason and the Virtues of Randomization" (Harcourt 2006a). In the article, I suggest that our lack of empirical knowledge should chasten our crime and punishment claims, and make us perhaps rely more on chance and randomization. I will not elaborate those points further here, but suggest only that they raise serious doubts about the ability of the state to properly identify and deal with the causes of crime. The track record, as I see it, is abysmal. This leaves me favoring less rather than more government intervention in the crime and punishment area across the board-not only as it relates to the actuarial turn (or, as I have argued elsewhere, to order maintenance), but also as it relates to community-based punishment practices as well as larger public policies that are justified on the basis of crime fighting. I am deeply concerned that the rhetoric of fighting crime is far too powerful a tool and tends to exercise too much justificatory force.

Though we may disagree here, the exchange with Sapir elucidates two corollary but important points. First, my second critique involves a costbenefit analysis and, as a result, it requires that we carefully calibrate our conclusions to any potential benefits. Some benefits may be so great that we may be willing to pay the price of a ratchet. It is for this reason that I make a distinction based on the egregiousness of the criminal offense. Sapir is undoubtedly right that the category of "heinous and egregious crimes" is theoretically problematic and ideologically loaded. But that, I take it, is 
inevitable and it points to our responsibility, as ethical and political agents, to properly police those ideological lines. ${ }^{6}$

Second, Sapir draws our attention to the distinction between punishment and regulatory prevention, and asks why Against Prediction is limited to punishment only. This is an important intervention. My three critiques of prediction do indeed extend beyond the penal sphere to the area of preventative detention and civil commitment, and I discuss the case of violent sexual predators (Harcourt 2007a, 14). The first two critiques operate in exactly the same fashion, and the third critique is also perfectly relevant as long as we are willing to question-as I and others, including Sapir and Carol Steiker (1997) are-the jurisprudential distinction between preventative, administrative practices and punitive sanctions. Once again, the harms may need to be recalibrated in the event that they are any less severe, but the analytic framework applies flawlessly.

\section{Distorting Our Conception of Just Punishment: Foucault on Discipline, Governmentality, and Power/Knowledge}

If profiling is potentially inefficient or alternatively may come at too high a price, then how exactly did actuarial instruments develop such traction in the field of crime and punishment? Why have they begun to colonize our thinking and practices of policing and punishing? The answer is complex but tied to what I call "the pull of prediction" (Harcourt 2007a, 174): our technical advances in the ability to collect data, categorize, compute, and predict have seduced us into believing that future dangerousness is at the core of just punishment. Our desire to know the criminal, to categorize him, and insure against future risk has led us to embrace the actuarial turn and, in the process, has displaced a fundamental tenet of just punishment, namely that similarly situated persons should be treated equally regardless of their membership in any particular ethnic, racial, or other group.

Ariela Gross, in her article "History, Race, and Prediction," and Sapir urge me to locate this third critique more explicitly within the Foucauldian models of discipline and governmentality. "Foucault, who was so present in

6. In contrast to the "ratchet effect" (Harcourt 2007a, 3) critique, the first critique addresses only the purported efficiency benefits of profiling (assuming a rational choice framework and deterrence) and demonstrates that those benefits themselves may be elusive. It does not reach the next stage of a cost-benefit analysis and does not assess potential costs, since it offers an internal critique of the law enforcement rationale for profiling. The third critique, which I discuss next, includes a normative argument about just punishment. There is no reason, though, that a consequentialist thinker could not assess the third critique through a cost-benefit lens. Not everyone will want to do so, especially not deontologists or social theorists, but it is not impervious to a cost-benefit analysis. For these reasons, the egregiousness of the criminal offense is potentially relevant to all three critiques. 
Harcourt's first book, lies only beneath the surface in Against Prediction," Sapir writes, and "a more explicit engagement with Foucault" would have helped decipher the links between, inter alia, actuarial and clinical methods (Sapir 2008, 259). Gross outlines how the actuarial turn in crime and punishment could be located within the context of "changing thinking about risk in a variety of fields of law" and suggests that these changes can be usefully analyzed from "a Foucauldian perspective" (Gross 2008, 238, see this issue).

It is indeed important to relate "the pull of prediction" back to Michel Foucault's work, if only to shed light on the unique and theoretically ambiguous nature of the actuarial turn. The truth is, the actuarial fits uncomfortably in the two dominant Foucauldian frameworks-discipline and governmentality. The first model, brilliantly developed in Discipline and Punish (1975), serves well to interpret and analyze the rehabilitative project that blossomed in corrections through the mid-twentieth century. Discipline, which was trained on the soul of the individual and sought to transform, reshape, and correct the delinquent - after, naturally, having constructed the delinquentwas intimately connected with the actuarial project. As I emphasize in Against Prediction, the actuarial impulse grew precisely from a desire to know the individual offender better and to administer an individual outcome with greater precision, in the context of both "the individualization of punishment" - to borrow the title of Raymond Saleilles's famous 1898 monographand the advent of indeterminate sentencing, parole boards, and the turn to rehabilitation (Harcourt 2007a, 42-45). The actuarial emerged first in the parole context as a way to assess whether a particular prisoner was likely to have been rehabilitated and could be paroled safely. Actuarial instruments were a central component of the individualization of punishment, which is vital to the third critique because I would like to suggest, contra Frederick Schauer (2003), that the actuarial was not about a preference for the general over the particular. To the contrary, it fed perfectly into the disciplinary project to "control the individual, neutralize his dangerousness, modify his criminal dispositions, and to only stop when those effects have been achieved" (Foucault 1975, 23).

But the actuarial fits uncomfortably in the disciplinary framework because it no longer seeks to normalize the delinquent in the same manner. There are also important differences with regard to the role of the judge. At the height of the disciplinary, the judge no longer simply determined guilt, but instead embodied a wide range of expertise from psychiatry to counseling to social work to education, administration, and correction, and took responsibility for the soul of the convict (22-27). Now, by contrast, the use of actuarial instruments has de-responsibilized the judge and parole board member. Now they simply fill in a table, add a few numbers, and read the answer. The judge is no longer an expert, but a mere scribe, a rapporteur. Others have done the work, and they have the expertise-the 
"actuarians," as the state of Illinois referred to them explicitly in the 1930s. This de-responsibilization is captured nowhere as well as in a passage from the leading parole board authority's Handbook for New Parole Board Members: "The thing that keeps parole board members awake at night is the fear that they will release someone and that person will commit a serious crime... Validated, actuarial risk assessment tools can significantly increase your ability to assess risk more accurately" $(2003,35)$.

None of this fits well with the disciplinary model, and for this reason, many have been tempted to explore Foucault's later lectures on biopolitics and governmentality. In those lectures, delivered at the Collège de France between 1976 and 1979, Foucault began to sketch a theoretical framework that revolved around the idea of "sécurité" — which he later renamed "governmentality" - and populations, a framework that seemed to apply better to the emerging practices of selective incapacitation. It was focused on populations rather than the individual. Foucault played with a number of different illustrations to distinguish the concept of governmentality from that of discipline, none better though than the example of the different responses to epidemics over the centuries: while the juridical model of exclusion was reflected in the exclusion of lepers in the Middle Ages, and the disciplinary model of control was reflected in the regimentation of the plague in the sixteenth and seventeenth centuries, the biopolitical model of population management is reflected in the administrative apparatus applied to the outbreak of smallpox beginning in the eighteenth century. This last model-a type of the larger category of governmentality-manifested itself "completely differently" and in the following terms:

not so much to impose a discipline, though there is some recourse to that, but rather to count how many people have smallpox, at what age and with what effects, what mortality, what lesions, what consequences, what risks we take with inoculation, what is the probability that an individual might die or get smallpox despite being inoculated, what are the statistical effects on the population in general. (Foucault 2004a, 12)

The concept of governmentality that Foucault began to sketch in his lectures has been elaborated since the 1990s by a number of critical theorists (see, e.g., Rose and Miller 1992; Burchell, Gordon, and Miller 1991) and continues to guide critical work today. Giorgio Agamben made fruitful use of the model of biopolitics - as a form of governmentality - in Homo Sacer (1998), where he describes how political regimes measure, control, regulate, and manipulate populations from the perspective of bare life-of mere physical existence. In their discussion of the "new penology," Malcolm Feeley and Jonathan Simon (1992) locate the actuarial precisely within the governmentality paradigm $(450,452)$.

Ariela Gross rightly draws on the governmentality framework, suggesting that the engineers of the actuarial may not in fact be focused on individual 
correction and rehabilitation, or on crime reduction and deterrence, but instead merely on managing and counting populations (Gross 2008, 238). These elements of the actuarial do indeed lend themselves to the idea of governmentality - of regulating populations, not individual souls, of securitizing, neutralizing, documenting, and controlling large groups of persons. But the focus on populations rather than individuals misses one of the central dimensions of the actuarial-namely, the desire to individualize the prediction and reduce false positives, to determine whether this particular offender is likely to reoffend, is a dangerous person, is a violent sexual predator. It is the specific and particular sexual offender across the street from you, living in that apartment or house that you can see through your window that we must identify, document, publicize, and contain or exclude. To be sure, the extent of this individualizing impulse to predict better may resonate more in some contexts than in othersin the case of sexual predators, for example, as well as parole releases, IRS audits, and federal sentencing. Gross's contribution is precisely to question how well it resonates in the case of racial profiling and to ask whether the individualizing impulse is performed differently with regard to young men of color. This is an important corrective; it does suggest that we may need to individualize our own analysis of the different tools and actuarial techniques. But there remains, to my mind, an important disjuncture between these actuarial impulses and the idea of simply managing populations. The desire to predict, especially the desire to minimize false positives, remains in large part an individualizing impulse.

As a result, I did not find it especially helpful to narrowly deploy Foucault's disciplinary and governmentality frameworks, and thought it better, this time around, to rely instead on the overarching theoretical framework of the will to knowledge. In this project I thus explored the set of concrete desires that I see reflected in the actuarial turn: the desire to know the criminal, the urge to categorize, and the impulse to insure. It is these concrete desires and impulses that help make better sense of the embrace of actuarial instruments. The desire to count, to predict, to know-the desire, in Hacking's (1990) words, to tame chance-reflects precisely the desire to control the future by knowing individuals.

In this sense, the theoretical intervention in Against Prediction draws importantly on the broader poststructuralist insight regarding power/knowledge (see generally Harcourt 2007b), as well as on the writings of Ian Hacking (1990) and Nikolas Rose (2002) regarding the notion of taming chancethe idea of using probabilistic methods to control the individual and shape the future (Harcourt 2007a, 41-45)? Like Mariana Valverde (2007, 160),

7. It also draws, in the more specific discussion of the urge to insure, on the work of Tom Baker and Jonathan Simon (2002) who are continuing to explore notions of risk and insurance (Harcourt 2007a, 185). 
my approach contests the idea that governmentality is a new mode of governance that, in an epochal or evolutionary way, has displaced discipline. Discipline and governmentality coexist, along with other forms of governance such as biopolitics and sovereignty (see Harcourt 2001, 149-50). Unlike Valverde, though, my approach emphasizes the larger power/knowledge dimension and, especially, the "will to know" project that others, such as Hacking, have emphasized in their writings.

Resisting the invitations of Sapir and Gross to place the actuarial within the logic of either discipline or governmentality, I contend then that the broader genealogical enterprise at the core of poststructuralism offers a powerful lens for the study of punishment practices. In the context of the actuarial turn, it raises the following set of questions: How did we come to believe that predictions of future dangerousness are the proper basis for administering just punishment and at what cost to society and the contemporary subject?

Two final points. First, Sapir is undoubtedly right that clinical prediction, which was more closely tied to Foucauldian discipline, operates in a similar way as actuarial prediction. There is no operative distinction between the two for purposes of my three critiques, so long as the clinical judgment depends on group offending differentials-which is most often the case. If this condition is met, both clinical judgment and actuarial instruments will have similar effects in terms of potential inefficiency, the ratchet effect, and distorting our conceptions of just punishment. The condition, though, is very important. The key point that motivates the three critiques is that the profiling methods are based on differences in group offending rates.

Finally, Gross asks at the end of her essay what is wrong with the fact that these prediction tools may have been developed in the social sciences, outside the legal realm (Gross 2008, 241). My critique does, indeed, betray a certain amount of optimism about the legal realm, as if only home-spun ideas of justice could possibly be right. My concern about exogenous influence, though, does not stem from privileging one discipline over the other, but from trepidations regarding the importing and exporting of ideas. Discourses in all disciplines develop resistance and counterresistance through multidimensional processes that involve the contestation and challenging of ideas. (The three review articles here are a prime example!) Implants and transplants, in contrast, often take place without that same resistance. They often travel without their critiques. Sapir says this best when he notes that "one sense in which the Americanization tendency is disturbing is that often ideas and policies travel, but their important critiques stay home" (Sapir $2008,254)$. That is precisely why the exogenous shock of actuarial instruments seems problematic to me. The prediction instruments were embraced in the law, but the skepticism and critiques stayed at home. 


\section{CLARIFYING THREE LARGER STRUCTURAL MATTERS IN AGAINST PREDICTION}

The three review articles also raise larger questions about the overall argument in Against Prediction. Having revisited the specific critiques in detail, I turn now to these structural matters.

\section{The Accuracy of Actuarial Instruments}

Sapir remarks, correctly, that Against Prediction "does not challenge the assumption that prediction actually works" (260). This raises an important structural issue: the entire argument in Against Prediction is premised on one central assumption, namely that the actuarial methods developed over the past century and now being utilized predict accurately.

Now as I mention in Against Prediction, there are significant questions about the reliability and validity of even the most popular actuarial instruments (Harcourt 2007a, 82-83). Interrater consistency scores are often low, as are some validation findings on subsequent samples. Even some of the staunchest supporters of actuarial instruments are not always particularly sanguine (Monahan and Swanson 2007).

No doubt, another book of the same title could be written challenging the assumption of accuracy. That, however, would be a different book, and it would not need to address efficiency arguments or selective incapacitation: if the instruments are not accurate, there is no possible argument for their use. In this book, I intentionally assumed that the instruments work in order to engage the very strongest arguments for prediction. Against Prediction joins issue at the very heart of the actuarial turn. ${ }^{8}$

\section{The Relationship Between the Three Critiques}

Margalioth also raises an important structural point. He emphasizes that the first two critiques are mutually exclusive, and that, together, they are in sharp tension with the third. How can we assume, for purposes of the first critique, that individuals are responsive to policing, but reject, for purposes of the second critique, all rational choice assumptions? Moreover, if we do adopt an efficiency-based cost-benefit approach in the first two critiques

8. Incidentally, this also explains why the book focuses on actuarial prediction rather than clinical judgment (although I do discuss at length the clinical school shooter profile at Harcourt 2007a, 291, note 117). There is a general perception today in the United States that actuarial instruments are far more accurate and useful than clinical predictions. This is not the case in other countries. Canada, for instance, still relies more heavily on clinical models, though the actuarial is on the rise (Vacheret 2005). 
and "if such an optimal policy calls for the use of profiling," then, Margalioth asks, "why should 'our conception of just punishment' matter?" (Margalioth 2008,246 ). How do the three critiques function together?

This is an excellent question and it calls for a very precise though somewhat technical answer. In Against Prediction, I offer two immanent critiques of the two leading arguments for the use of actuarial methods--the arguments from efficiency and selective incapacitation-in order to motivate a genealogical power/knowledge critique that explores how we have come to embrace the actuarial despite its likely failures, and at what cost. This is a mouthful, I confess, but it is the most accurate presentation of the book.

The first and second critiques are indeed mutually exclusive, but not by accident. They rely on contradictory assumptions about human action precisely because they respond to the two strongest arguments for profilingnamely, the efficiency and the selective incapacitation arguments. These two strongest arguments for profiling are themselves mutually exclusive: if rational choice assumptions do in fact hold, as per the efficiency argument, then profiling will eliminate all offending disparities and there will be no selective incapacitation to be had. The two principal arguments for profiling themselves rest on incompatible assumptions, and as a result the inverse is true as well: if we assume elasticity, profiling will eliminate any offending differentials and thereby eliminate the possibility of a ratchet effect. In this sense, the first two internal critiques-just like the two strongest arguments for profiling-work as critiques in the alternative.

Together, the first two critiques motivate the third, more fundamental genealogical inquiry: Why have we come to embrace the actuarial turn despite these flaws in the arguments? Why do so many believe the efficiency claim despite the lack of any evidence regarding comparative elasticities? Why has no one even raised the issue of comparative elasticities until now? And why have we failed to appreciate the devastating consequences of a potential ratchet effect? The answers to these questions thus form the basis of the third critique: we have embraced the actuarial turn, I suggest, because of our desire to know the criminal, to categorize, and insure against future risk. The intense desire for certainty has rendered these actuarial techniques irresistibly seductive, with devastating consequences for the core principle of equal treatment at the heart of just punishment. ${ }^{9}$

In sum, the three critiques do work together, but not in classical harmony. The first two internal critiques motivate the third and most important intervention.

9. At the 2007 Berlin meeting of the Law \& Society Association, Pat O'Malley asked why the desire for certainty had taken the shape it had-this embrace of actuarial methods. The answer is complex but, I would suggest, it is integrally tied to our late-modern condition, one where rational explanations, social science, and economic ideology have gained ascendance. O'Malley also emphasized the political dimensions of this, of which I have no doubt. A whole other book-a fascinating book-could be written on the topic. 


\section{On Race and Prediction}

One final major structural issue has to do with the role of race in Against Prediction. To drive home a central point of the book-namely that the mathematical and cost-benefit problems potentially plague all actuarial methods, not just racial profiling-I made the ill-advised and simplifying claim that the problem with racial profiling is not race, but profiling. I was trying to move the racial profiling debate from the issue of racism to the question of profiling. In her review essay, Gross argues that "although Harcourt insists at the outset that he is telling us a story that is distinct from race-- the problem .... is about the profiling, not race'-I came away from his book convinced that we should tell this as a racial history as well" (Gross 2008, 239). Gross sketches a number of fruitful directions in which a racial history could go, concluding that "a study of criminology and criminal justice practices in the United States simply cannot be divorced or disentangled from the history of racial subordination" (240).

Gross is right-race does indeed play a key and disturbing role in the history of the actuarial. The first parole prediction instrument, developed in 1927 by Ernest Burgess, included the race/nationality of the father as one of twenty-one factors that predicted success or failure on parole (Harcourt 2007a, 57). Burgess's model was implemented by the Illinois Board of Paroles in 1933 and, as a result, race was used expressly as one factor in the "prognasio" that served as the basis for the decision whether to parole an inmate. This continued for many decades. In fact, when California began using a parole prediction instrument in the 1970 s, it used an actuarial device that relied on race. The first California "Base/Expectancy Score" narrowed in on race and only three other factors: prior commitments, offense type, and number of escapes (Simon 1993, 173). There is no doubt, also, that race motivates our discomfort with racial profiling.

Perhaps a much better way to frame the issue of race, then, is not to extricate it from the racial profiling equation but instead to borrow from Lani Guinier and Gerald Torres's (2002) metaphor of the miner's canary. Just like the canary, whose distress is a warning that the air in the mine is poisoned, the troubling aspect of race in the debate over racial profiling points to the larger problems of profiling for all groups. Race is the first place where we see the poison, but it is a poison that affects everyone else.

Let me close then by reframing the point. The problems with racial profiling involve both race and profiling. Like the canary in the coal mine, the trouble surrounding racial profiling alerts us to other problems with the use of actuarial methods more generally. The mathematics of profiling and the overlooked detrimental costs to the profiled populations affect all profiling techniques, whether they focus on race or recidivism, gender or sexual orientation, national origin, or other classifications. We may, as a society, decide 
to apply less scrutiny to some of these classifications than to others, but the effects are the same. It is for this reason that the critiques of profiling are so relevant today, post $9 / 11$, in a world in which we may increasingly police and punish on the basis of religious affiliation or national origin (Harcourt forthcoming).

\section{CONCLUSION}

Thanks to Gross, Margalioth, and Sapir, I can now reformulate with greater precision the three critiques that I presented in Against Prediction. First, the actuarial methods developed over the twentieth century and being used today rely exclusively on differences in offending rates and do not take account of the comparative elasticities of the different populations. Because members of different populations may in fact respond differently to policing and punishment, the use of existing profiling techniques may actually increase overall offending in society. If we had perfect knowledge of comparative elasticities and offending rates, then we could administer statistical discrimination in a perfectly efficient manner. But that is neither realistic nor likely in this lifetime.

Second, if we assume that people are perfectly inelastic to policing, the use of existing profiling techniques will cause a ratchet effect on the targeted population with devastating consequences on their employment, education, family, and other social outcomes. These are costs that are often ignored because the targeted individuals are criminally culpable. They are, however, costs that often overwhelm any benefits associated with actuarial methods. Selective incapacitation-as one underlying theory of punishment that might justify a ratchet effect-is also problematic because it does not treat similarly situated offenders equally but instead uses membership in racial, gender, or other groups as a way to determine who is similarly situated.

Finally, and most importantly, if rational choice theorists are wrong to extol the virtues of profiling and if proponents of selective incapacitation have failed to appreciate the devastating consequences on profiled populations, then why have so many people come to embrace the actuarial turnwith the limited exception of racial profiling? The reason, I suggest, traces to our deep desire to know, our urge to categorize, and our impulse to insure against risk. We have been seduced by these techniques, driven by our desire for certainty - at the expense of fundamental notions of just punishment. Although the actuarial turn fits uncomfortably within the two leading paradigms of Foucauldian thought-discipline and governmentality-the actuarial can be profitably understood through a will to knowledge lens. These desires to know the criminal, to categorize, and to insure are what fuel our continued and misguided quest to predict deviance.

It is for these reasons that I remain against prediction. 


\section{REFERENCES}

Agamben, Giorgio. 1998. Homo Sacer: Sovereign Power and Bare Life. Trans. Daniel HellerRoazen. Stanford, CA: Stanford University Press.

Baker, Tom, and Jonathan Simon. 2002. Embracing Risk. In Embracing Risk: The Changing Culture of Insurance and Responsibility, ed. Tom Baker and Jonathan Simon, 1-25. Chicago: University of Chicago Press.

Bar-Ilan, Avner, and Bruce Sacerdote. 2001. The Response to Fines and Probability of Detection in a Series of Experiments. Working Paper 8638, National Bureau of Economic Research, Cambridge, MA.

Bjerk, David. Forthcoming. Racial Profiling, Statistical Discrimination, and the Effect of a Colorblind Policy on the Crime Rate. Journal of Public Economic Theory.

Blumkin, Tomer, and Yoram Margalioth. 2006. Targeting the Majority: Redesigning Racial Profiling Rules. Yale Law E Policy Review 24:317-45.

Bruce, Andrew A., Emest W. Burgess, and Albert M. Harno. 1928. A Study of the Indeterminate Sentence and Parole in the State of Illinois. Joumal of the American Institute of Criminal Law and Criminology, 19 (1) Part II: 1-306 (May).

Burchell, Graham, Collin Gordon, and Peter Miller, eds. 1991. The Foucault Effect: Studies in Governmentality. London: Harvester Wheatsheaf.

Dominitz, Jeff, and John Knowles. 2005. Crime Minimization and Racial Bias: What Can We Learn From Police Search Data? PIER Working Paper 05-019. http://ssm.com/ abstract $=719981$ (accessed October 5, 2007).

Feeley, Malcolm M., and Jonathan Simon. 1992. The New Penology: Notes on the Emerging Strategy of Corrections and Its Implications. Criminology, 30:449-74.

Foucault, Michel. 1975. Surveiller et punir: Naissance de la prison [Discipline and Punishment: The Birth of the Prison]. Paris: Editions Gallimard.

- 1997. Il faut défendre la société: Cours au Collège de France [Society Must Be Defended: Lectures at the Collège de France], (delivered 1976). Paris: Seuil/Gallimard.

- 2004a. Sécurité, Territoire, Population: Cours au Collège de France [Security, Territory, Population: Lectures at the Collège de France], (delivered 1977-78). Paris: Seuil/Gallimard.

- 2004b. Naissance de la Biopolitique: Cours au Collège de France [The Birth of Biopolitics: Lectures at the Collège de France], (delivered 1978-1979). Paris: Seuil/Gallimard.

Gross, Ariela. 2008. History, Race, and Prediction: Comments on Harcourt's Against Prediction. Law 8 Social Inquiry 33 (1): 235-42.

Guinier, Lani, and Gerald Torres. 2005. The Miner's Canary: Enlisting Race, Resisting Power, Transforming Democracy. Cambridge, MA: Harvard University Press.

Hacking, lan. 1990. The Taming of Chance. New York: Cambridge University Press.

Handbook for New Parole Board Members. 2003. Association of Paroling Authorities International and the National Institute of Corrections. http://www.apaintl.org/en/ aw_publications.html (accessed October 5, 2007).

Harcourt, Bernard, E. 2003a. The Shaping of Chance: Actuarial Models and Criminal Profiling at the Turn of the Twenty-First Century. University of Chicago Law Review $70: 105-28$.

2003b. From the Ne'er-Do-Well to the Criminal History Category: The Actuarial in Criminal Law. Law $\mathcal{B}$ Contemporary Problems 66:99-151.

—. 2004. Rethinking Racial Profiling: A Critique of the Economics, Civil Liberties, and Constitutional Literature, and of Criminal Profiling More Generally. University of Chicago Law Review 71 (4): 1275-381.

2006a. Post-Modern Meditations on Punishment: On the Limits of Reason and the Virtues of Randomization (A Polemic and Manifesto for the Twenty-First Century). Journal of Social Research 74 (2): 307-46. 
2006b. Language of the Gun: Youth, Crime, and Public Policy. Chicago: University of Chicago Press.

- 2007a. Against Prediction: Profiling, Policing, and Punishing in an Actuarial Age. Chicago: University of Chicago Press.

—_. 2007b. An Answer to the Question: "What Is Poststructuralism?" Public Law Working Paper 156, University of Chicago. http://ssm.com/abstract=970348 (accessed October 5, 2007).

_ 2007 c. From the Asylum to the Prison: Rethinking the Incarceration RevolutionPart II: State Level Analysis. Olin Working Paper 335, University of Chicago Law \& Economics. http://ssrn.com/abstract=970341 (accessed October 5, 2007).

_ _ Forthcoming. Muslim Profiles Post 9/11: Is Racial Profiling an Effective Counterterrorist Measure and Does It Violate the Right to be Free from Discrimination? In Security and Human Rights, ed. Benjamin Goold and Liora Lazarus. Oxford: Hart Publishing

Heaton, Paul. 2006. Understanding the Effects of Anti-Profiling Policies. Working paper, University of Chicago. http://home.uchicago.edu/ psheaton/workingpapers/ racialprofiling.pdf (accessed March 2006).

Margalioth, Yoram. 2008. Looking at Prediction from an Economics Perspective: A Response to Harcourt's Against Prediction. Law $\mathcal{F}$ Social Inquiry 33 (1): 243-52.

Monahan, John, and Jeffrey Swanson. 2007. The Challenge of Preventing Violence Is Not Just an American Problem. The Observer, Sunday, April 22.

Monahan, John, and Laurens Walker. 2006. Social Science in Law: Cases and Materials. Westbury, CT: Foundation Press.

Persico, Nicola. 2002. Racial Profiling, Fairness, and Effectiveness of Policing. American Economic Review 92:1472-497.

Roberts, Dorothy E. 1999. Foreword: Race, Vagueness, and the Social Meaning of OrderMaintenance Policing. Journal of Criminal Law Ë Criminology 89:775-836.

Rose, Nikolas. 2002. At Risk of Madness. In Embracing Risk: The Changing Culture of Insurance and Responsibility, ed. Tom Baker and Jonathan Simon, 209-37, Chicago: University of Chicago Press.

Rose, Nikolas, and Peter Miller. 1992. Political Power Beyond the State: Problematics of Government. British Journal of Sociology, 43 (2): 173-205.

Saleilles, Raymond. 1898. L'Individualisation de la peine: Étude de criminalité sociale [The Individualization of Punishment]. Paris: F. Alcan.

Sapir, Yoav. 2008. Against Prevention? A Response to Harcourt's Against Prediction on Actuarial and Clinical Predictions and the Faults of Incapacitation. Law $\mathbb{G}$ Social Inquiry 33 (1): 253-64.

Schauer, Frederick. 2003. Profiles, Probabilities, and Stereotypes. Cambridge MA: Harvard University Press.

Simon, Jonathan. 1993. Poor Discipline. Chicago: University of Chicago Press.

Steiker, Carol S. 1997. Punishment Theory and the Criminal-Civil Procedural Divide. Georgetown Law Journal 85:775-819.

Travis, Jeremy. 2000. But They All Come Back: Rethinking Prisoner Reentry. Papers From the Executive Sessions on Sentencing and Corrections, 7, Research in Brief, National Institute of Justice, U.S. Department of Justice, Washington, DC.

Vacheret, Marion, and Cousineau Marie-Marthe. 2005. L'évaluation du risque de récidive au sein du systeme correctionel canadien: regards sur les limites d'un système [The evaluation of the risk of recidivism in the Canadian correctional system: looking at the limits of a system]. Déviance et Sociéte 29 (4): 379-97.

Valverde, Mariana. 2007. Genealogies of European States: Foucauldian Reflections. Economy and Society 36 (1): 159-78. 
***

HeinOnline -- 33 Law \& Soc. Inquiry 2842008 
Law 8 Social Inquiry

Volume 33, Issue 1, 285-290, Winter 2008

\section{Book Notes}

\section{CONTENTS}

RighTS/EQUALITY UNDER LAW ................................................................ 286

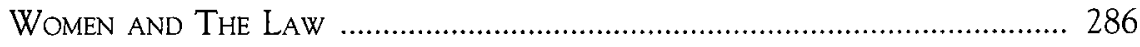

CRiminal Justice and Social Control ................................................ 286

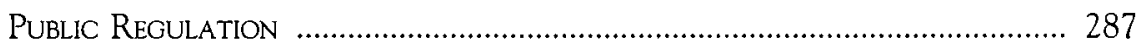

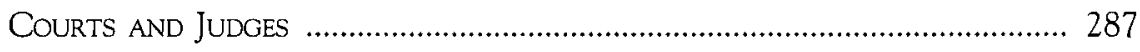

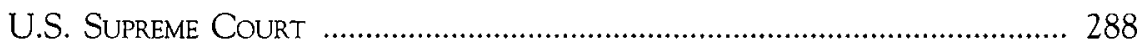

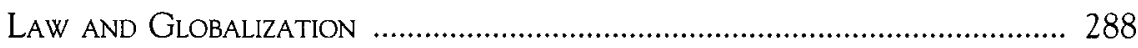

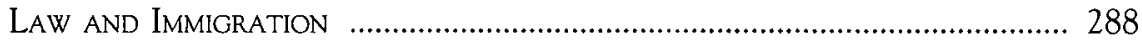

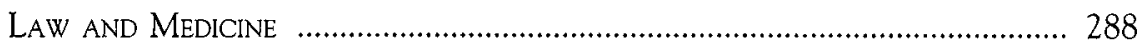

LAW AND FAMILY RELATIONSHIPS ......................................................... 289

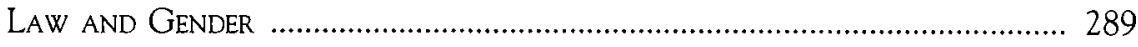

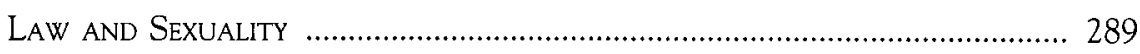

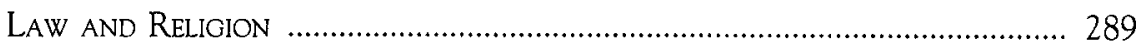

LAW AND THE ENVIRONMENT ............................................................ 290

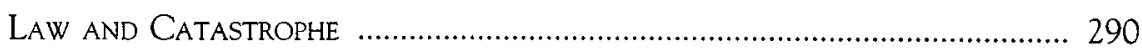

